Available online on 15.01.2019 at http://jddtonline.info
Journal of Drug Delivery and Therapeutics
Open Access to Pharmaceutical and Medical Research
(c)11-18, publisher and licensee JDDT, This is an Open Access article which permits unrestricted
non-commercial use, provided the original work is properly cited

Open $\odot$ Access

Research Article

\title{
Phytochemicals and GC-MS analysis of bioactive compounds present in ethanolic leaves extract of Taraxacum officinale (L).
}

\author{
Sasikala P1, Ganesan S1, ${ }^{,}$, Jayaseelan T1, Azhagumadhavan S1, Padma M1, Senthilkumar S1, Mani P2 \\ ${ }^{1}$ P.G. and Research Department of Zoology and Biotechnology, A.V.V.M. Sri Pushpam College (Autonomous), Poondi - 613 503, Thanjavur District,
} Tamil Nadu, India.

${ }^{2}$ Dept. of Biotechnology, Annai College of Arts and Science, Kumbakonam, Tamilnadu, India.

\begin{abstract}
Objective: To identify the phytochemical constituents present in ethanolic leaves extract of Taraxacum officinale (T. o) and to elucidate the bioactive compounds.

Methods: The fresh leaves of T. officinale $(1000 \mathrm{~g})$ were shade dried at room temperature for 30 days and the dried leaves were made into a fine powder. The ethanolic leaves extract obtained was dried with help of desiccator and rotatory evaporator. The dried samples tested for phytochemical analysis and bioactive compounds profiling through GC-MS analysis.

Results: The phytochemical screening studies showed presence of alkaloids, flavonoids, phenol, cardiac glycosides and anthraquinones. in the leaves extract of T. officinale. GC-MS analysis showed 10 essential bioactive compounds and it revealed the presence of significant anticancer, Antimicrobial and antidiabetic compounds.

Conclusions: The ethanol extract of T. o possess the most important phytochemical compounds and it has various medicinal properties to cure dangerous diseases and disorders.
\end{abstract}

Keywords: Taraxacum officinale, Phytochemicals analysis, GC-MS analysis, Biological compounds.

Article Info: Received 19 Nov 2018; Review Completed 30 Dec 2018; Accepted 02 Jan 2019; Available online 15 Jan 2019

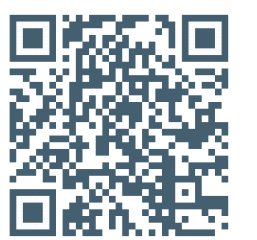

\section{Cite this article as:}

Sasikala P, Ganesan S, Jayaseelan T, Azhagumadhavan S, Padma M, Senthilkumar S, Mani P, Phytochemicals and GC-MS analysis of bioactive compounds present in ethanolic leaves extract of Taraxacum officinale (L)., Journal of Drug Delivery and Therapeutics. 2019; 9(1):90-94 DOI: http://dx.doi.org/10.22270/jddt.v9i1.2175

Dr. Ganesan Sivamani, Assistant Professor, PG \& Research Department of Zoology and Biotechnology, A.V.V.M. Sri Pushpam College (Autonomous), Poondi, Thanjavur - 613503, Tamil Nadu, India

\section{INTRODUCTION}

India is the chief producer of medicinal herbs and is appropriately called the botanical garden of the world 1 . Plant use in the treatment of diseases is as old as civilization 2, 3 and complementary medicine is still a major part of habitual treatments of different maladies ${ }^{4}$. The medicinal plants are useful for healing as well as for curing of human diseases because of the presence of phytochemical constituents 5 . Medicinal plants are a precious heritage for humanity; our ancestors used these plants to ensure their health and transmitted their knowledge and their experiences generation to generation. About $80 \%$ of the world population uses this mode of therapy (Azaizeh et al., 2003) especially in undeveloped countries when the modern medical system was absent (Tabuti et al., 2003) 6,7.

Medicinal plants constitute the main source of new pharmaceuticals and healthcare products ${ }^{8}$. Plants are a rich source of secondary metabolites with interesting biological activities. In general, these secondary metabolites are a ISSN: 2250-1177

[90] significant source with various structural arrangements, functions and properties 9 . Plants are capable of synthesizing an overwhelming variety of low-molecular-weight organic compounds called secondary metabolites, usually with unique and complex structures. Many metabolites have been found to possess interesting biological activities and find applications, such as pharmaceuticals, insecticides, dyes, flavours and fragrances. Plants used for traditional medicine contain a wide range of substances that can be used to treat chronic as well as infectious diseases ${ }^{10}$. Phytochemicals are naturally occurring in the medicinal plants like leaves, stem bark, fruits and roots that have defence mechanism and protect from various diseases. Natural products from plants are called secondary metabolites are the end products of primary metabolites such as carbohydrates, amino acid and chlorophyll lipid so on. They are synthesis large variety of chemical substances known as secondary metabolites which include alkaloids, steroids, flavonoids, terpenoids, glycoside, saponin, tannins, phenolic compounds etc ${ }^{11}$. Phytochemicals were the chemicals that present naturally in plants.

CODEN (USA): JDDTAO 
Nowadays these phytochemicals become more popular due to their countless medicinal uses. Phytochemicals play the main role in the number of diseases such as asthma, arthritis, cancer etc. Extraction and characterization of many active phytocompounds from these green factories have given birth to some high activity profile drugs 12 . The active principle of many drugs found in plants is secondary metabolites. Therefore basic phytochemical investigation is vital ${ }^{13}$. The identification and isolation of such active compounds make it a more effective therapeutic application. It present consumes from taking certain plants that have no medicinal value or poisonous to them. It will lead to better understanding of diseases.

According to the World Health Organization, medicinal plants would be the greatest source to obtain an array of drugs. Thus, such plants should be investigated to a better understanding of their properties, safety practices in addition to usefulness 14. Gas chromatography-mass spectrometry (GC-MS) is a method that combines the features of gas-liquid chromatography and mass spectrometry to identify various substances within a test sample. Applications of GC-MS include drug detection, fire investigation, environmental analysis, explosives investigation, and identification of unknown samples. In the last few years, gas chromatography-mass spectrometry (GCMS) has become firmly established as a key technological platform for secondary metabolite profiling in both plant and non-plant species 15, 16, 17. Gas- Chromatography-Mass Spectrometry (GC-MS) is a helpful technique for reliable profiling of secondary metabolites ${ }^{18-19}$. GC-MS can also be used in airport security to detect substances in luggage or on human beings. However, fewer reports are available with respect to the pharmacological properties of the plant 20 . GCMS is one of the best techniques to identify the bioactive constituents of long-chain branched chain hydrocarbons, ester, acids, alcohols etc.

Taraxacum is a large genus of flowering plants in the Asteraceae family. Taraxacum officinale (L) is a very well known medicinal herb in Ayurvedic medicine since times immoral. Taraxacum is the largest genus of Asteraceae family, is a herbaceous perennial herb commonly called dandelion, found especially in lawns and along roadsides, and it is used as a medicinal herb and in food preparations. Dandelion has been extensively used as traditional folk medicine, and as a diuretic in modern phytotherapy. It is used to treat a variety of diseases including cancer 21, 22 in China, Arab and Native America. In Chinese, Arabian and Native American traditional medicine it is used to treat a variety of diseases including cancer 23,24 . To explore the medicinal importance the rhizomes of Taraxacum officinale $\mathrm{L}$ were screened primarily for the phytochemicals present in it and was analyzed using GC-MS.

\section{MATERIALS AND METHODS}

\section{Plant Collection and Preparation of plant extracts}

Fresh, healthy, and young leaves of Taraxacum officinale were collected from the Himalayan region, India. The leaves were cleaned and dried in shade for 7 days and then ground well to a fine powder. About $500 \mathrm{~g}$ of dry powder was extracted with ethanol $(80 \%)$ at $70^{\circ} \mathrm{C}$ by continuous hot percolation using Soxhlet apparatus. The extraction was continued for $24 \mathrm{hrs}$, and the ethanolic extract was then filtered and kept in a hot air oven at $40^{\circ} \mathrm{C}$ for $24 \mathrm{hrs}$ to evaporate the ethanol from it. A dark brown residue was obtained. The residue was kept separately in airtight containers and stored in a deep freezer.

\section{Phytochemical analysis tests}

Phytochemical analysis of an ethanolic extract of Taraxacum officinale leaves for secondary metabolites such as alkaloids, flavonoids, carbohydrates, proteins, phenols, saponins, tannins, terpenoids, phytosterols, and phlobatannins was done using standard methods 25 .

\section{Gas Chromatography-Mass spectrometry (GC-MS) analysis}

The GC-MS analysis was carried out using a Clarus 500 Perkin- Elmer (Auto System XL) Gas Chromatograph equipped and coupled to a mass detector Turbo mass gold Perking Elmer Turbomas 5.2 spectrometer with an Elite-1 (100\% Dimethyl ply siloxane), $300 \mathrm{~m} \times 0.25 \mathrm{~mm} \times 1 \mu \mathrm{m} \mathrm{df}$ capillary column. The instrument was set to an initial temperature of $110^{\circ} \mathrm{C}$ and maintained at this temperature for $2 \mathrm{~min}$. At the end of this period, the oven temperature was raised up to $280^{\circ} \mathrm{C}$, at the rate of an increase of $5^{\circ} \mathrm{C} / \mathrm{min}$, and maintained for $9 \mathrm{~min}$. Injection port temperature was ensured as $250^{\circ} \mathrm{C}$ and Helium flow rate as $1 \mathrm{ml} / \mathrm{min}$. The ionization voltage was $70 \mathrm{eV}$. The samples were injected in split mode as 10:1. Mass Spectral scan range was set at 45 450 (MHz). The chemical constituents were identified by GCMS. The fragmentation patterns of mass spectra were compared with those stored in the spectrometer database using National Institute of Standards and Technology Mass Spectral database (NIST-MS). The percentage of each component was calculated from the relative peak area of each component in the chromatogram.

\section{Identification of Compounds}

Interpretation of mass spectrum of GC-MS was conducted using the database of National Institute Standard and Technology (NIST) having more than 62,000 patterns. The spectrum of the known component was compared with the spectrum of the known components stored in the NIST library. The name, molecular weight and structure of the components of the test materials were ascertained.

\section{RESULTS AND DISCUSSION}

\section{Phytochemical analysis}

Table 1: Phytochemical Analysis of Taraxacum officinale (L)

\begin{tabular}{|c|l|l|}
\hline S.No & Test & Result \\
\hline 1 & Alkaloids & + \\
\hline 2 & Flavonoids & + \\
\hline 3 & Saponins & - \\
\hline 4 & Tannins & - \\
\hline 5 & Terpenoids & - \\
\hline 6 & Phenol & + \\
\hline 7 & Cardiac glycosides & + \\
\hline 8 & Anthroquinones & + \\
\hline
\end{tabular}

$=$ Absence; $+=$ Presence

The results of phytochemical characterization ethanolic extracts of T. officinale are shown in Table 1. Phytochemical analysis of an ethanolic extract of the plant also revealed the presence of alkaloids, flavonoids, phenol, cardiac glycosides, anthraquinones. Phytochemical analysis of an ethanolic extract of the plant also revealed the absence of saponins, tannins, terpenoids.

\section{Gas Chromatography-Mass spectrometry (GC-MS) analysis}

Phytochemical components in ethanolic extract of $\mathrm{T}$. officinale by GC-MS report. The GC-MS analysis revealed the presence of 10 compounds (Table 2 and 3) from the 
ethanolic leaves extract of T. officinale (Figure 1). From the results, it was observed that presence of 3-Cyclopentene-1ethanol, 2,2,4-trimethyl-, (+)-2-Bornanone, Isobornyl thiocyanoacetate, 1,2-cis-1,5-trans-2,5-dihydroxy-4-methyl1-(1-hydroxy-1-isopropyl)cyclohex-3-ene, 2-Trifluoro acetoxytridecane, Tridecane, Dodecane, 2,6,11-trimethyl-,
Phenol, 2,6-bis(1,1-dimethylethyl)-, Decane, 2,4,6-trimethyl-, 2,2-bis[4-[(4,6-dichloro-1,3,5-triazin-2-yl)oxy]phenyl]1,1,1,3,3,3-hexafluoropropane. Above these compounds were identified based on the RT value, molecular weight, molecular formula, etc (Fig 1) and table 2, 3.

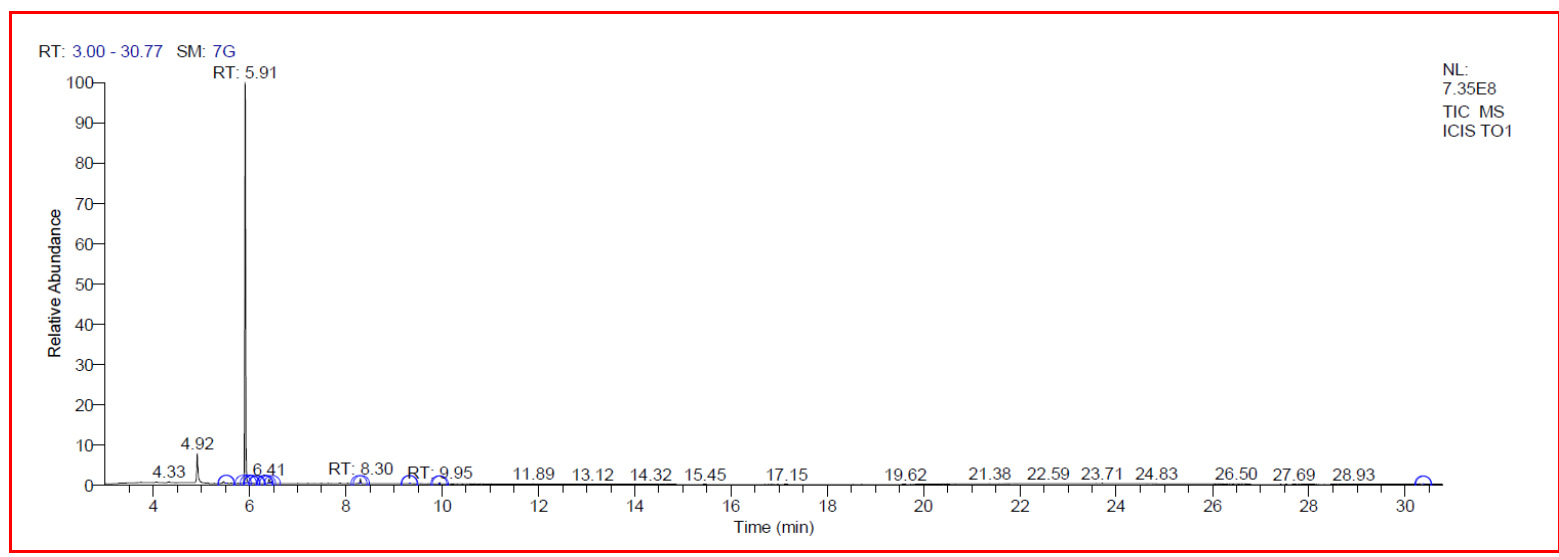

Figure 1: GC-MS CHROMATOGRAM OF Taraxacum officinale (L)

Table 2: Physical properties of bioactive compounds in Taraxacum officinale (L)

\begin{tabular}{|l|l|l|l|l|}
\hline S.No & Name of the Compound & RT & Molecular Formula & CAS Registry Number \\
\hline 1 & 3-Cyclopentene-1-ethanol, 2,2,4-trimethyl- & 5.53 & $\mathrm{C}_{10} \mathrm{H}_{18} \mathrm{O}$ & $80514-13-2$ \\
\hline 2 & (+)-2-Bornanone & 5.91 & $\mathrm{C}_{10} \mathrm{H}_{16} \mathrm{O}$ & $464-49-3$ \\
\hline 3 & Isobornyl thiocyanoacetate & 6.05 & $\mathrm{C}_{13} \mathrm{H}_{19} \mathrm{NO}_{2} \mathrm{~S}$ & $115-31-1$ \\
\hline 4 & $\begin{array}{l}\text { 1,2-cis-1,5-trans-2,5-dihydroxy-4-methyl-1-(1- } \\
\text { hydroxy-1-isopropyl)cyclohexane-3-one }\end{array}$ & 6.15 & $\mathrm{C}_{10} \mathrm{H}_{18} \mathrm{O}_{3}$ & $87096-70-6$ \\
\hline 5 & 2-Trifluoroacetoxytridecane & 6.32 & $\mathrm{C}_{15} \mathrm{H}_{27} \mathrm{~F}_{3} \mathrm{O}_{2}$ & $116465-18-0$ \\
\hline 6 & Dodecane & 6.41 & $\mathrm{C}_{12} \mathrm{H}_{26}$ & 112403 \\
\hline 7 & Dodecane, 2,6,11-trimethyl- & 8.30 & $\mathrm{C}_{15} \mathrm{H}_{32}$ & $31295-56-4$ \\
\hline 8 & Phenol, 2,6-bis(1,1-dimethylethyl)- & 9.33 & $\mathrm{C}_{14} \mathrm{H}_{22} \mathrm{O}$ & $128-39-2$ \\
\hline 9 & Pentadecane & 9.95 & $\mathrm{C}_{15} \mathrm{H}_{32}$ & 629629 \\
\hline 10 & $\begin{array}{l}\text { 2,2-bis[4-[(4,6-dichloro-1,3,5-triazin-2- } \\
\text { yl)oxy]phenyl]-1,1,1,3,3,3-hexafluoropropane }\end{array}$ & 30.38 & $\mathrm{C}_{21} \mathrm{H}_{8} \mathrm{C}_{14} \mathrm{~F}_{6} \mathrm{~N}_{6} \mathrm{O}_{2}$ & $\mathrm{NA}$ \\
\hline
\end{tabular}

RT= Retention Time

Table 3: GC-MS Analysis of Taraxacum officinale (L)

\begin{tabular}{|c|c|c|c|c|}
\hline Name of the Compound & $\begin{array}{l}\text { Nature of the } \\
\text { Compound }\end{array}$ & Structure & $\begin{array}{c}\text { Molecular Weight } \\
\text { (g/mol) }\end{array}$ & Activity \\
\hline $\begin{array}{l}\text { 3-Cyclopentene-1- } \\
\text { ethanol, 2,2,4-trimethyl- }\end{array}$ & Alcohol & & 154.253 & $\begin{array}{l}\text { Antibacterial } \\
\text { activity }\end{array}$ \\
\hline$(+)$-2-Bornanone & $\begin{array}{l}\text { Monoterpene } \\
\text { oxide }\end{array}$ & & 152.2334 & $\begin{array}{c}\text { Antitumor, } \\
\text { Analgesic } \\
\text { Antibacterial, } \\
\text { Anti-inflammatory } \\
\text { Sedative, } \\
\text { Fungicide, } \\
\text { Anticancer. }\end{array}$ \\
\hline $\begin{array}{c}\text { Isobornyl } \\
\text { thiocyanoacetate }\end{array}$ & Ester & & 253.360 & $\begin{array}{c}\text { Antiseptic } \\
\text { property }\end{array}$ \\
\hline
\end{tabular}




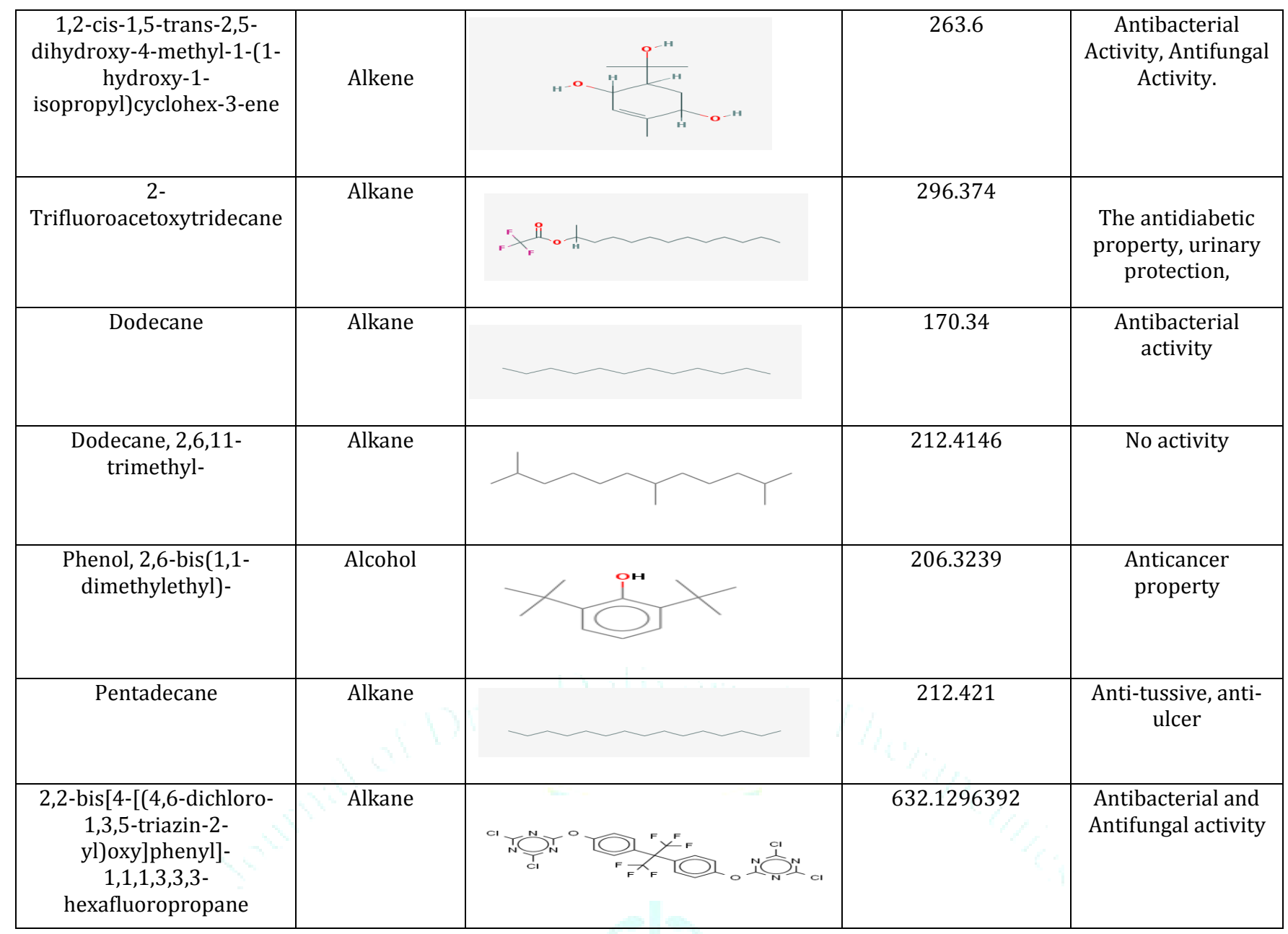

3-Cyclopentene-1-ethanol, 2,2,4-trimethyl- is an aromatic alcoholic compound. It has $5.53 \mathrm{RT}$ value, $\mathrm{C}_{10} \mathrm{H}_{18} \mathrm{O}$ molecular formula and 154.253 molecular weight. This compound exhibited varying levels of antimicrobial activity against the investigated bacteria 26 .

(+)-2-Bornanone is an aromatic monoterpene oxide compound. It has $5.91 \mathrm{RT}$ value, $\mathrm{C}_{10} \mathrm{H}_{16} \mathrm{O}$ molecular formula and 152.2334 molecular weight. It has antitumor, analgesic antibacterial, anti-inflammatory sedative, fungicide, anticancer activities. It was used as an anti-cancer agent reported by Mariat George et al., (2015) 27.

Isobornyl thiocyanoacetate is an aromatic ester compound. It has $6.05 \mathrm{RT}$ value, $\mathrm{C}_{13} \mathrm{H}_{19} \mathrm{NO}_{2} \mathrm{~S}$ molecular formula and 253.360 molecular weight. It has antiseptic property. It was marketed as insecticides ${ }^{28}$.

1,2-cis-1,5-trans-2,5-dihydroxy-4-methyl-1-(1-hydroxy-1isopropyl)cyclohexane-3-ene is an aromatic alkene compound. It has $6.15 \mathrm{RT}$ value, $\mathrm{C}_{10} \mathrm{H}_{18} \mathrm{O}_{3}$ molecular formula and 263 molecular weight. This compound and their constituents are contemporary applied in food preservation and in the manufacture of medicinal antimicrobial agents and disinfectants (Voda et al., 2003). ${ }^{29}$

2-Trifluoroacetoxytridecane is an aliphatic alkane compound. It has 6.32 RT value, $\mathrm{C}_{15} \mathrm{H}_{27} \mathrm{~F}_{3} \mathrm{O}_{2}$ molecular formula and 296.374 molecular weight. This compound has an antimicrobial activity ${ }^{30}$.

Dodecane is an aliphatic alkane compound. It has 6.41 RT value, $\mathrm{C}_{12} \mathrm{H}_{26}$ molecular formula and 170.34 molecular weight. Some alkanes (i.e., n-hexane, n-dodecane and n- hexadecane) were previously reported to increase metabolite production by acting as oxygen-vectors $31-33$.

Dodecane, 2,6,11-trimethyl- is an aliphatic alkane compound. It has $8.30 \mathrm{RT}$ value, $\mathrm{C}_{15} \mathrm{H}_{32}$ molecular formula and 212.4146 molecular weight. It has no activity 34 .

Phenol, 2,6-bis(1,1-dimethylethyl)- is an aromatic alcoholic compound. It has $9.33 \mathrm{RT}$ value, $\mathrm{C}_{14} \mathrm{H}_{22} \mathrm{O}$ molecular formula and 206.3239 molecular weight. It has an anticancer property and cytotoxic property. This compound has been reported as cytotoxic compounds by inhibiting various types of neoplastic cell lines and some of the compounds are potent anticancer agents $35-36$.

Pentadecane is an aliphatic alkane compound. It has 9.95 RT value, $\mathrm{C}_{15} \mathrm{H}_{32}$ molecular formula and 212.421 molecular weight. This compound has Antitussive and antiulcer activity 37.

2,2-bis[4-[(4,6-dichloro-1,3,5-triazine-2-yl)oxy]phenyl]$1,1,1,3,3,3$-hexafluoropropane is an aromatic alkane compound. It has $30.38 \mathrm{RT}$ value, $\mathrm{C}_{21} \mathrm{H}_{8} \mathrm{C}_{14} \mathrm{~F}_{6} \mathrm{~N}_{6} \mathrm{O}_{2}$ molecular formula and 632.1296392 molecular weight. The TPC could be used as an important indicator of the antioxidant capacity due to a high redox ${ }^{38}$.

\section{CONCLUSION}

The phytochemical analysis of the plants is also important and pharmaceuticals companies for the novel drugs for the treatment of various diseases. In the present investigation 10 compounds from the ethanolic leaves extract of Taraxacum officinale (L). were identified by Gas-chromatography- Mass spectrometry (GC-MS) analysis. The biological activities of CODEN (USA): JDDTAO 
each of the identified phytocomponents used for antimicrobial and anti-cancer activities. Biochemical compound identification of the plant constituents was conducted depending upon their retention time (RT), molecular formula, molecular weight and mass spectral data, as well as by computer search mass spectral databases. Gas chromatography and mass spectroscopy analysis showed the existence of various compounds with different chemical structures. Thus, improving the methods for qualitative and quantitative determination of medicinal plants are very important for quality assessment in the medicinal plant industry. In addition, the phytochemical analysis gives a good monitoring method of the seasonal changes of the active constituents and during cultivations and harvesting which assists in collecting the largest amounts of the active constituents. We report the presence of some of the important components resolved by GC-MS analysis and their biological activities. Thus this type of GC-MS analysis is the first step towards understanding the nature of active principles in this medicinal plant and this type of study will be helpful for further detailed study.

\section{ACKNOWLEDGEMENT}

The author is also very grateful to the Secretary and Correspondent and the Principal of A.V.V.M. Sri Pushpam College (Autonomous), Poondi-613 503, Thanjavur (Dt.) for providing the excellent infrastructure and necessary facilities to carry out my research work successfully.

\section{REFERENCES}

1. Ahmedull M, Nayar MP. Red data book for Indian plants. Botanical Survey of India. 1999; 4

2. Fabricant D, Farnsworth N. The value of plants used in traditional medicine for drug discovery. Environmental Health Perspectives. 2001; 109(1):69-75.

3. Wamidh HT. Anticancer and Antimicrobial Potential of PlantDerived Natural Products. In: Iraj Rasooli, ed. PhytochemicalsBioactivities and Impact on Health. Croatia. 2011; 141-58.

4. Alviano D, Alviano A. Plant extracts: search for a new alternative to treat microbial diseases. Current Pharmaceutical Biotechnology. 2009; 10(1):106-21.

5. Nostro A, Germano MP, Danelo V, Marino A, Cannatelli MA. Extraction methods and bioautography for evaluation of medicinal plant antimicrobial activity; Lett. Appl. Microbial 2000; 30: 379-384. 6. Azaizeh H, Fulder S, Khalil K, Said O. Ethnobotanical knowledge of local Arab practitioners in the Middle Eastern region. Fitoterapia. 2003; 74(1-2):98- 108.

7. Tabuti JRS, Lye KA, Dhillion SS. Traditional herbal drugs of Bulamogi, Uganda: plants, use and administration. Journal of Ethnopharmacology. 2003; 88(1):19-44.

8. Misra A. J Med Plants Res. 2009; 3:1140-1146.

9. de-Fatima A, Modolo LV, Conegero LS, Pilli RA, Ferreira CV, Kohn LK, de- Carvalho JE, Lactones and their derivatives: biological activities, mechanisms of action and potential leads for drug design, Curr Med Chem. 2006; 13:3371-3384.

10. Duraipandiyan V, Ayyanar M, Ignacimuthu S. Antimicrobial activity of some ethnomedicinal plants used by Paliyar tribe from Tamil Nadu, India. BMC Complement. Altern. Med. 2006; 6:35-41.

11. Ghazi A. Introduction to pharmacognosy, Ahmadu Bello University Press, Ltd. Zaria, Nigeria. 1990; 45-47.

12. Mandal V, Mohan Y, Hemalatha S. Pharmacog Rev. 2007; 1:7-18.

13. Dobelis IN. Magic and Medicine of plants. The Reader Digest Association Inc., New York, Montreal. 1993; 8-48.

14. Nascimento GGF, Locatelli J, Freitas PC, Silva GL. Antibacterial activity of plant extracts and phytochemicals on antibiotic-resistant bacteria. Brazil Journal Microbiology. 2000; 31(4): 886-891.

15. Robertson DG. Metabonomics in toxicology: A review. Toxicol. Sci. 2005; 85:809-22.
16. Fernie AR, Trethewey RN, Krotzky AJ, Willmitzer L. Metabolite profiling: From diagnostics to systems biology. Nat Rev Mol Cell Biol. 2004; 5:763-9.

17. Kell DB, Brown M, Davey HM, Dunn WB, Spasic I, Oliver SG. Metabolic footprinting and systems biology: The medium is the message. Nat Rev Microbiol. 2005; 3:557-65.

18. Subramanian S, Ramakrishnan N. Chromatographic fingerprint analysis of Naringi crenulata by HPTLC technique. Asian Pacific Journal of Tropical Biomedicine. 2011; 1(2):195-8.

19. Mariswamy Y, Gnaraj WE, Johnson M. Chromatographic fingerprint analysis of steroids in Aerva lanata L by HPTLC technique. Asian Pacific journal of tropical biomedicine. 2011; 1(6):428-33.

20. Cowan MM. Plants products antimicrobial agents. Clin Microbial Rev. 1999; 14:564-584.

21. Clare BA, Conroy RS, Spelman K. The diuretic effect in human subjects of an extract of Taraxacum officinale folium over a single day, J Altern Complement Med. 2009; 15 (8):929-34.

22. Sigstedt SC, Hooten CJ, Callewaert MC, Jenkins AR. Evaluation of aqueous extracts of Taraxacum officinale on growth and invasion of breast and prostate cancer cells, Int J. Oncol. 2008; 32(5):1085-90.

23. Clare BA, Conroy RS, Spelman K, The diuretic effect in human subjects of an extract of Taraxacum officinale folium over a single day, J Altern Complement Med. 2009; 15(8):929-34.

24. Sigstedt SC, Hooten CJ, Callewaert MC, Jenkins AR et al., Evaluation of aqueous extracts of Taraxacum officinale on growth and invasion of breast and prostate cancer cells, Int J Oncol. 2008; 32(5):1085-90.

25. Harborne JB. Phytochemical Methods. London: Chapman and Hall Ltd.; 1973; 49-188.

26. Remmal A, Bouchikhi T, Rhayour K, Ettayebi M. Improved method for the determination of antimicrobial activity of essential oils in agar medium, J. Essent. Oil Res. 1993; 5:179-184.

27. Mariat George. Phytochemical and Antioxidant studies on the essential oil of the rhizome of Curcuma aeruginosa (Roxb). International Research Journal of Pharmacy. 2015; 6(8): 573-579.

28. Ware GW: The Pesticides Book,. Thomson Publications, Fresno, CA, USA. 1994.

29. Voda K, Boh B, Vrtacnik M, Pohleven F. Effect of the antifungal activity of oxygenated aromatic essential oil compounds on the white-rot Trametes versicolor and the brown-rot Coniophora puteana. Int. Biodeterior. Biodegrad. 2003; 51:51-59.

30. Jessica A, Rao MRK, Anthony J, Prabhu K, Johnson WMS, Balasubramanian BS, Sundaram L, Dinakar S. The GC-MS Study of One Ayurvedic Preparation Katakakhadiradi Kashayam. Int. J. Pharm. Sci. Rev. Res. 2016; 39(2):216-224.

31. Xu F, Yuan QP, Zhu Y. Improved production of lycopene and $\beta$ carotene by Blakeslea trispora with oxygen-vectors. Process Biochem. 2007; 42:289-293.

32. Lai LT, Tsai TH, Wang TC. Application of oxygen vectors to Aspergillus terreus cultivation. J. Biosci. Bioeng. 2002; 94:453-459.

33. Peng C, Huang H, Ji X, Liu X, Ren L, Yu W, You J, Lu J. Effects of nhexadecane concentration and a two-stage oxygen supply control strategy on arachidonic acid production by Mortierella appina ME-1. Chem. Eng. Technol. 2010; 33:692-697.

34. Ramalingam Vidhya and Rajangam Udayakumar. Gas Chromatography-Mass Spectrometry (GC-MS) Analysis of Ethanolic Extracts of Aerva lanata (L.). International Journal of Biochemistry Research \& Review 2015; 7(4):192-203.

35. Cerchiara T, Blaiotta G, Straface VS, Belsito E, Liguori A, Luppi B, Bigucci F, Chidichimo G. Biological Activity of Spartium junceum L. (Fabaceae) Aromatic Water. Nat. Resources, 2013; 4:229-234.

36. Da Silva CEL, Minguzzi S, da Silva RCL, Matos MFC, Toffoli D, de Carvalho JE, Ruiz ALTG, da Costa WF, Simionatto E. Chemical Composition and Cytotoxic Activity of the Root Essential Oil from Jatropha ribifolia (Pohl) Bill (Euphorbiaceae). J Braz. Chem. Soc., 2015; 26(2):233-238.

37. Gnanasundaram I, Balakrishnan K. Characterization of Bioactive Compounds in Ethanolic Extract of Cissus vitiginea Leaves Using GCMS Technique. IOSR Journal of Applied Chemistry. 2017; 10, 9(3):24-27.

38. Viuda-Martos M, Navajas Y, Zapata, ESJ, López F, Pérez-Álvarez JA. Flavour Frag J 2010; 25:13-19. 